\title{
Two new species of Pileolaria (Polychaeta: Spirorbidae) from the Southern Hemisphere with a brief review of related species
}

\begin{abstract}
A.V. Rzhavsky
A.N. Severtsov Institute of Ecology and Evolution, RAS, Leninskij Prospekt 33, Moscow, Russia 119071.e-mail:rzhavskij@mail.ru

ABSRACT: Two new polychaete species of family Spirorbidae are described, both similar to those species of Pileolaria that have the distal part of the brood-chamber smooth and domed or bilobed. Pileolaria connexa sp.n. from Kerguelen Island (and probably Palmer Archipelago), unlike most species of the genus, commonly retains the primary operculum (plate and talon) distal to the brood chamber, and has sickle chaetae with unusually long distal serrated parts of the blades. Pileolaria invultuosa sp.n. from Bouvet Island and Adelie Land (and perhaps Enderby Land and Signy Island) sheds the primary operculum before the brood chamber is fully developed and has distal serrated parts of sickle chaetae blades similar in length to proximal thick parts of the blades. Both new species are similar, but unusual amongst this group, in having a shallow calcified cap restricted to the distal part of the brood chamber. The primary opercula of both species differ from each other (and from those of most Pileolaria species) in the shape and position of the distal plates talons.
\end{abstract}

KEY WORDS: Spirorbidae, Pileolaria, Antarctic, Subantarctic.

\section{Два новых вида рода Pileolaria (Polychaeta: Spirorbidae) из южного полушария с кратким обзором родственных видов}

\begin{abstract}
А.В. Ржавский
Институт проблем экологии и эволюции им. А.Н. Севериова РАН, Ленинский пр., 33, Москва, 119071.e-mail:rzhavskij@mail.ru

РЕЗЮМЕ: Описано два новых вида полихет семейства Spirorbidae из рода Pileolaria, относящихся к группе видов с гладкой выпуклой или слегка раздвоенной дистальной частью выводковой камеры. Pileolaria connexa sp.n. с о. Кергелен (и, вероятно, архипелага Палмер) в отличие от остальных часто сохраняет дистальную пластинку первичного оперкулюма прикреплённой к выводковой камере, а зазубренная часть лезвия его серповидных щетинок необычайно длинная. Pileolaria invultuosa sp.n.c о. Буве и Земли Адели (и, возможно, Земли Эндерби и о-ва Сигни), как и большинство остальных Pileolaria теряет первичный оперкулюм после формирования выводковой камеры и имеет равные размеры зазубренной и гладкой базальной части лезвия серповидных щетинок. Оба вида отличаются от остальных видов этой группы неглубокой зоной кальцинации дистальной части выводковой камеры, а также строением и положением когтя дистальной пластинки первичного оперкулюма.
\end{abstract}

КЛЮЧЕВЫЕ СЛОВА: Spirorbidae, Pileolaria, Антарктика, Субантарктика. 


\section{Introduction}

Traditionally family Serpulidae has been divided into three subfamilies: Spirorbinae, Serpulinae and Filograninae (e.g. Rioja, 1923; Fauvel, 1927). Pillai (1970) elevated the Spirorbinae to family status. Later a number of authors (ten Hove, 1984; Smith, 1991; Kupriyanova, 2003; Kupriyanova et al., 2006 etc.) based on the results of cladistic analyses of morphological and molecular data sets concluded that spirorbins are monophyletic and nested inside Serpulidae. Nevertheless elaborated taxonomic system below the family level in the Spirorbidae needs to be revised if the rank of the group is to be lowered to subfamily and such a revision is clearly out of scope of the current paper. So I maintain family Spirorbidae for practical reasons.

Pileolaria Claparede, 1868 is largest spirorbid's genus (about 20 species) belong to subfamily Pileolariinae which representatives incubate embryos within cup formed by invagination of opercular ampula. Genera Pileolaria and Simplaria Knight-Jones, 1978 have completely closed brood chamber without soft-walled sac; their primary opercula do not fused with mature brood chamber and usually detached. Pileolaria differs from Simplaria in having sickle chaetae at $3^{\text {rd }}$ chaetigers.

Several species of Pileolaria are similar in having smooth-domed hemispherical or bilobed brood chambers. Some are difficult to distinguish from others. Pileolaria moerchi (Levinsen, 1883), described from the south of Greenland (Levinsen, 1883, as Spirorbis) was recorded by Bush (1905) from Alaska and the North Atlantic and by Pixell (1912) from Vancouver Island. Similar Vancouver Island material was used by Potswald (1977), in his detailed studies of opercular brooding, but the Vancouver species was found to be undescribed and belonging to another genus of the Pileolariinae (KnightJones 1978; 1984) Simplaria potswaldi (KnightJones, 1978). P. moerchi sensu Harris (1969), from the Subantarctic Palmer Archipelago, Antarctic Peninsula, was a different and much smaller species, somewhat resembling Pileolaria tegwyni Vine, 1977 from New Zealand (Vine,
1977), as discussed by P. and E.W. KnightJones (1994). P. moerchi sensu Harris (1968) from Naples was also small and later identified by Harris (1969) as a Marseilles species Pileolaria heteropoma (Zibrowius 1968).

Pileolaria berkeleyana (Rioja, 1942) described from western Mexico (Rioja, 1942 as Spirorbis, subgenus Pileolaria) and recorded from the Galapagos Islands (Bailey, Harris, 1968), now appears circumglobal in the Northern Hemisphere. When first recorded from the Canary Islands (Knight-Jones E.W., KnightJones P., 1980), Azores and Mediterranean (Zibrowius, Bianchi, 1981) it seemed particularly abundant in harbours, as though recently invaded by shipping. A similar species, Pileolaria rosepigmentata (Uchida, 1971) was described from Japan (Uchida, 1971, as Laeospira). It was recorded from southern Britain as a recent invasion on immigrant Japanese Sargassum (KnightJones P. et al., 1975). British P. rosepigmentata can be distinguished from the smooth-domed variety "glabra" (Knight-Jones P., Knight-Jones E.W., 1977) of $P$. heteropoma described from the Mediterranean (Zibrowius, 1968, as Spirorbis sub-genus Laeospira), and from a similar Kenyan (Knight-Jones, 1972) species Pileolaria daijonesi Knight-Jones, 1972.

Knight-Jones P. et al. (1979) recorded $P$. rosepigmentata from Monterey Harbour (USA) and $P$. berkeleyana from more southern localities of the North American West Coast, from Palos Verdes to Panama. Later P. rosepigmentata was recorded from Australia and south of Africa (Knight-Jones P., Knight-Jones E.W., 1984). However, Thorp et al.(1986), concluded that P. rosepigmentata is a junior synonym of $P$. berkeleyana, the species they recorded from harbours at Falmouth and Plymouth. Similarly, Rzhavsky (1989) found P. rosepigmentata in Avacha Inlet, Kamchatka, but later (Rzhavsky, 1992) changed the species attribution to the oldername and, based on Russian collections, recorded P. berkeleyana from the Bering Sea, West Spitzbergen, Commander and Kurile Islands. Currently I'm placing all authentic records of "berkeleyana" and "rosepigmentata" in Pileolaria ex gr. berkeleyana. All the forms in the $P$. berkeleana-rosepigmentata complex may 
be conspecifics as well as sibling or pseudosibling species, including unusually large $P$. moerchi sensu stricto that might be just "giant" specimens of this or another species in the complex. This problem needs a special study with use of molecular genetics methods.

Meanwhile, in collections by French scientific expeditions, we found specimens of Pileolaria although similar, but distinctly different from those above. In my opinion there are two new species in this material from the Antarctic and Subantarctic, and they are described below.

\section{Material and methods}

The material studied here was mainly collected by French expeditions onboard R/V «Marion Dufresne», from several Subantarctic islands in 1974-1975 and 1980, and by the XII French Antarctic expedition to Adelie Land in 1962-1963. Some additional samples from other localities also were examined. Specimens were preserved in $70 \%$ ethanol; some of them were mounted without opercula in polyvinyllactophenol (PVL) for examination of chaetal structure. The holotypes are deposited in the Muséum Nationale d'Histoire Naturelle, Paris (MNHNP) and some paratypes are deposited in the Natural History Museum, London(NHML), National Museum of Wales (NMW) and in Kamchatka Institute of the Ecology and Environment of the Far East Branch of the Russian Academy of Sciences, Petropavlovsk-Kamchatsky (KIE). The latter are currently held in the author's collection in A.N. Severtsov Institute of Ecology and Evolution, Russian Academy of Sciences, Moscow (IEE).

\section{Results}

Genus Pileolaria Claparede, 1868 (emended Knight-Jones, 1984)

\section{Pileolaria connexa sp.n.}

Fig. $1 \mathrm{~A}-\mathrm{V}$.

MATERIAL EXAMINED. Holotype. MNHNP, Reg. No. UD 334, specimen with embryos in brood chamber and attached distal plate, in alcohol. $\mathrm{R} / \mathrm{V}$ «Marion Dufresne» MD 03, 25/62/CB 7 (17.04.74), south-east of Kerguelen Island $\left(50^{\circ} 01.7^{\prime} \mathrm{S}, 68^{\circ} 27.3^{\prime} \mathrm{E}\right)$, depth $172 \mathrm{~m}$, on empty serpulid tube.

Paratypes. 1) MNHNP, Reg. No. UD 335, 8 specimens in alcohol: including 6 of adult size with primary operculum only, 1 juvenile with primary operculum, and 1 with empty brood chamber fused with older one and replaced by new primary distal plate, label same as holotype; 2) MNHNP, Reg. No. UD 336, UD 337 - 18 specimens; NHML, Reg. No. 1994.2097-21012 - 10 specimens. In total 23 specimens in ethanol and 5 mounted on a PVL slide: including 16 with just brood chamber, 5 with brood chamber and attached distal plate, 4 juveniles with primary opercular plate, 2 of adult-size with such distal plate only and 1 with distal plate and developing brood chamber. Some free distal plates that became detached from the brood chamber are also kept in the vial. R/V «Marion Dufresne» MD 04, B 9/DC 19 (23.02.75), Baie de Swains, Kerguelen Island $\left(49^{\circ} 32.2^{\prime} \mathrm{S}, 6^{\circ} 39.4^{\prime} \mathrm{E}\right)$, depth $110 \mathrm{~m}$, on serpulid tubes; 3) MNHNP, Reg. No UD 338, UD 339, 24 specimens in alcohol and 3 mounted on a slide: including 19 with brood chamber only, 5 of adult-size with distal plate only and 3 with brood chamber and attached distal plate. Some free distal plates which had become detached from brood chambers also kept in the vial. $\mathrm{R} / \mathrm{V}$ «Marion Dufresne» MD 04, J 114/DC 272 (15.03.75), south-east of Kerguelen Island $\left(49^{\circ} 54^{\prime} \mathrm{S}, 70^{\circ} 24.4^{\prime} \mathrm{E}\right)$, depth $168 \mathrm{~m}$, on empty serpulid tubes; 4) MNHNP, Reg. No. UD $340-6$ specimens in ethanol: including 4 with brood chamber only and 2 juveniles with primary plates. R/V «Marion Dufresne» MD 04, B 8/DC 16 (23.02.75), Baie de Swains, Kerguelen Island $\left(49^{\circ} 31.2^{\prime} \mathrm{S}, 69^{\circ} 38.3^{\prime} \mathrm{E}\right)$, depth $21 \mathrm{~m}$, on serpulid tubes; 5) MNHNP Reg. No. UD $341-23$ specimens; KIE, Reg. No. 1/2502 - 10 specimens. In total 33 specimens in ethanol: including 12 juveniles with primary plates, 11 adults with brood chamber and attached distal plate; 5 with brood chamber only; 5 of adult-size with distal plate only, «Marion Dufresne» MD 03, 23/59/ CP 16 (16.04.74), south-east of Kerguelen Island $\left(49^{\circ} 59.2^{\prime} \mathrm{S}, 70^{\circ} 01.2^{\prime} \mathrm{E}\right)$, depth $168 \mathrm{~m}$, on empty serpulid tubes.

ADDITIONAL MATERIAL. (2 specimens, NHML) Spirorbis moerchi Levinsen sensu Harris, (1969, p. 159160, fig. 13 a-1 (non Levinsen, 1883)); same material mentioned as Pileolaria moerchi. sensu Harris (in KnightJones P, Knight-Jones E.W., 1994, fig. 6 G-J), Palmer Archipelago.

DESCRIPTION. Tube (Fig. 1A) white, planospiral, with one high median longitudinal ridge projecting a little beyond tube mouth and giving triangular cross-section, sometimes with indistinct peripheral flange, no more than 1.5 $\mathrm{mm}$ in whorl diameter (usually about $1 \mathrm{~mm}$ ).

Primary or juvenile operculum with concave distal plate, usually with short curved pointed talon (Fig. 1B, C), but two specimens with longer talon (Fig. 1D); many specimens of adult size only with this type of operculum; many others retain it distally on the developing or 


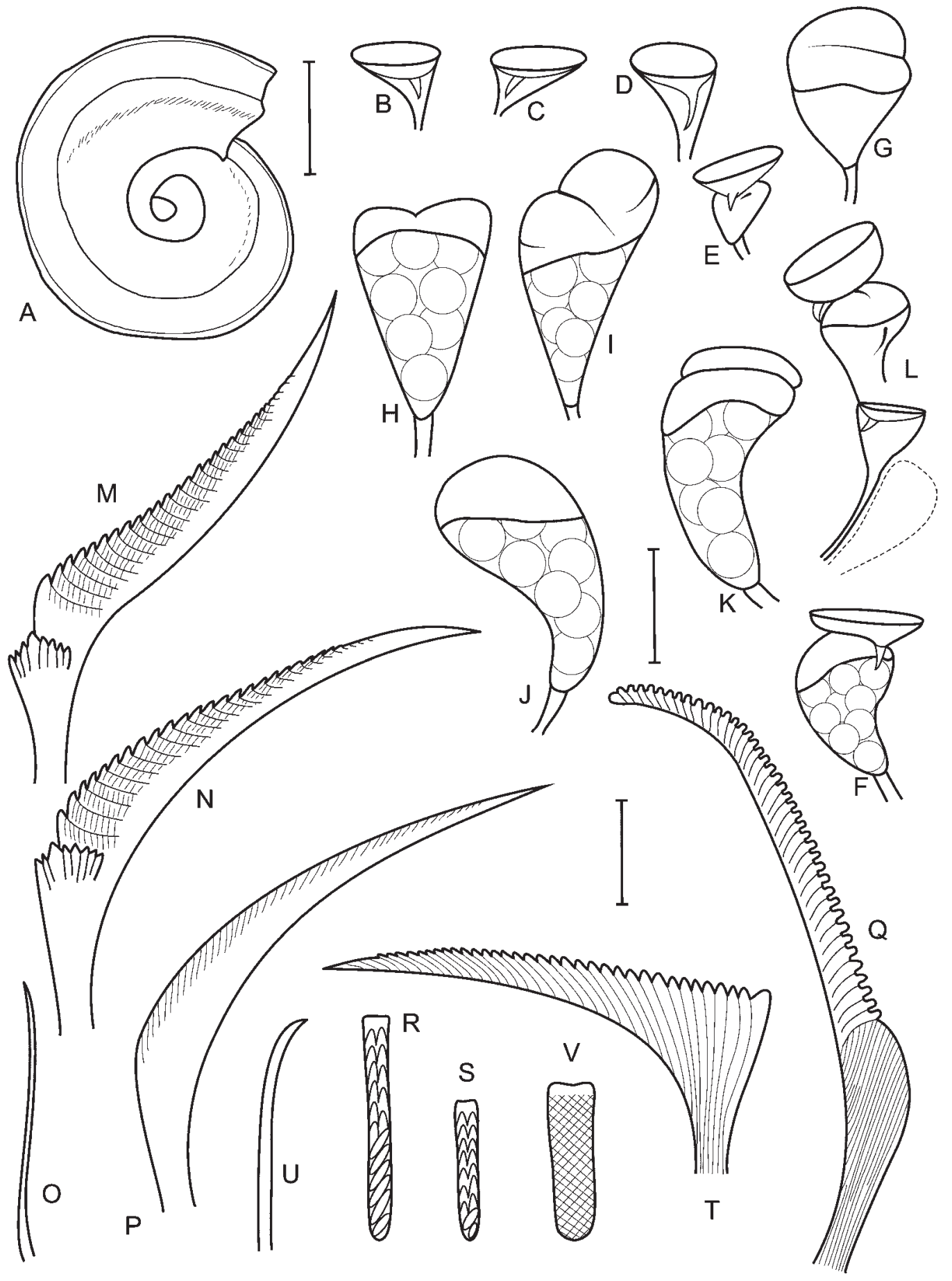


mature brood chamber (Fig. 1E, F). Primary operculum easily detached so that other specimens with brood chamber only (Fig. $1 \mathrm{G}-\mathrm{K}$ ). Operculum of primary type may replace the brood chamber after breeding (Fig. 1L). Distal calcified part of brood chamber with shallow sides, depth about half the transverse diameter, distally somewhat domed, divided into two unequal parts by distinct groove where talon of previous primary operculum is attached.

Collar and thoracic membrane with free dorsal margins. Collar chaetae (Fig. 1M, N) 36 per fascicle, bent, fin-and-blade, with coarsely serrated and distinctly cross-striated blades, usually with distinct gap between fin and blade, though gap may be very short in chaetae of small specimens and in shorter chaetae of large specimens. Capillary chaetae (Fig. 1O) also present in first fascicle. Chaetae of $2^{\text {nd }}$ and $3^{\text {rd }}$ thoracic chaetigers simple (Fig. 1P). Sickle chaetae (Fig. $1 \mathrm{Q})$ also present in $3^{\text {rd }}$ fascicle, each with very long serrated distal and short smooth basal parts of blades. Two thoracic tori on each side of body. Thoracic uncini (Fig. 1R, S) short (smallest of same length as those of abdomen, largest only 1.5 times longer) with blunt anterior peg and 2-1 longitudinal rows of teeth. About 10-15 abdominal chaetigers. Abdominal chaetae (Fig. 1T) flat geniculate with distinctly serrated, ta- pering, thin blade, with "knee" slightly projecting beyond shaft and with blade length same as that of collar chaetae; usually 1 per fascicle ( 2 per fascicle on some anterior chaetigers). A single hooked capillary chaeta (Fig. $1 \mathrm{U}$ ) observed on last abdominal chaetiger of one specimen (8 examined under a compound microscope). Abdominal uncini (Fig. $1 \mathrm{~V}$ ) with blunt anterior pegs and 7-8 longitudinal rows of teeth; uncini distribution fairly symmetrical on both sides of the body. Largest tori in the middleposterior part of abdomen. Preserved specimens uncoloured.

REMARKS. Material of "moerchi" examined by Harris (1969, fig. 13 a-k) was presented by two specimens, one of them with a primary operculum attached to the brood chamber. It seems to belong to this species indeed even though Harris (1969, fig. 13 b) figured a distinct flat-topped brood chamber. Re-examination of the material by Knight-Jones P. and KnightJones E.W. (1994, Fig. 6 G-J) and later by myself indicated that Harris's figure may have been a schematically drawn brood chamber with attached primary operculum (somewhat like Fig. $2 \mathrm{~J}$ in Knight-Jones $\mathrm{P}$ and Knight-Jones E.W. (1994). Harris's figure also shows (incorrectly) fairly extensive calcification proximally. This figure may have led Vine (1977) to

Fig. 1. Pileolaria connexa sp.n.

A - tube; B-D - variation in primary opercular plate and talon; E - operculum with distal plate and developing brood chamber; F - mature brood chamber with attached distal plate (holotype); G - empty brood chamber without distal opercular plate, top view; $\mathrm{H}-\mathrm{K}$ - mature brood chambers lacking distal opercular plates, frontal, top and side views; $\mathrm{L}$ - empty brood chamber fused with older distal plate, being replaced from below by new plate; M, N — collar chaetae with fin and blade; $\mathrm{O}-$ capillary chaeta from $1^{\text {st }}$ chaetiger, accompanying collar chaetae; $\mathrm{P}-$ simple chaeta from $2^{\text {nd }}$ and $3^{\text {rd }}$ chaetigers; $\mathrm{Q}$ - sickle chaeta from $3^{\text {rd }}$ chaetiger; $\mathrm{R}$ - largest thoracic uncinus; $\mathrm{S}$ - smallest thoracic uncinus; $\mathrm{T}$ - flat geniculate abdominal chaeta with serrated blade; $\mathrm{U}$ - abdominal hooked capillary chaeta; $\mathrm{V}$ - abdominal uncinus. Scale bars: A $-0.4 \mathrm{~mm}, \mathrm{~F}-\mathrm{L}-0.25 \mathrm{~mm}, \mathrm{M}-\mathrm{V}-0.01 \mathrm{~mm}$.

Рис. 1. Pileolaria connexa sp.n.

$\mathrm{A}$ - трубка; B-D - изменчивость дистальной пластинки и когтя первичного оперкулюма; $\mathrm{E}-$ оперкулюм с дистально пластинкой и формирующейся выводковой камерой; $\mathrm{F}$ - зрелая выводковая камера с прикреплённой дистальной пластинкой (голотип); $\mathrm{G}$ - пустая выводковая камера без дистальной пластинки, вид сверху; $\mathrm{H}-\mathrm{K}-$ зрелая выводковая камера без дистальной пластинки, вид спереди, сверху и с боков; L - пустая выводковая камера с прикреплённой старой дистальной пластинкой, замещающаяся новым оперкулюмом с дистальной пластинкой; M, N - воротничковые щетинки с крыловидным придатком; О - капиллярная волосовидная щетинка первого щетинкового сегмента, сопровождающая воротничковые щетинки; Р — простая щетинка 2-го и 3-го щетинковых сегментов; Q - серповидная щетинка 3-го щетинкового сегмента; $\mathrm{R}$ - наибольшая торакальная анцини; S - наименьшая торакальная анцини; T - плоская геникулирующая абдоминальная щетинка с зазубренным лезвием; $\mathrm{U}$ - капиллярная крючковидная абдоминальная щетинка; $\mathrm{V}$ - абдоминальная анцини. Масштабы: А - 0,4 мм, F-L - 0,25 мм, $\mathrm{M}-\mathrm{V}-0,01$ мм. 
suggest that Harris's species was the same as the New Zealand species $P$. tegwyni. In fact Harris's material has shallow calcification, extending proximally about half the diameter of the chamber. The area of calcification in P. tegwyni extends to a length about twice the diameter. The specimen with a primary operculum attached to the brood chamber with a pointed eccentric talon was similar to that found in $P$. connexa. All Pileolaria species have a period when the primary operculum is still present after the development of the brood chamber is completed, but that period is brief and rarely recorded. Harris (1969) figured a tube and sickle chaeta like those of $P$. connexa but I did not examine the chaetal structure in order to keep the specimens completely intact.

Retention of primary opercula plates distal to brood chambers of $P$. connexa is frequent, but it differs from retention of such plates in Bushiella Knight-Jones, 1973 (which includes Jugaria Knight-Jones 1978 as a subgenus), and Protoleodora Knight-Jones, 1984 (KnightJones, 1973, 1978, 1984; Rzhavsky, 1991, 1992). In Bushiella the more peripheral talons make a major contribution to the construction and protection of their brood chambers and are completely fused with brood chamber or firmly attached to its lateral wall by the talon. In Protoleodora primary operculum is slightly attached by the talon tip only to the concave distal part of brood chamber. In P. connexa the distal plate also is not attached firmly to the brood chamber but its connection is more like those in the transition stages of various species of Pileolaria opercula being developed for brooding (figured by Bailey, 1969; Knight-Jones and Thorp, 1984; Thorp, 1989). When the primary opercula are missing, $P$. connexa resembles several Pileolariinae in having a smooth rounded brood chamber, which may be distally bilobed.

S. potswaldi is easily distinguished by its lack of sickle chaetae and by its remarkable thoracic cloak (apron) extending posteriorly from the right side of the collar to about halfway down the abdomen. P. moerchi grows large (more than $4 \mathrm{~mm}$ in coil diameter), and it is very different in having helmet-like calcification twice as long as its transverse diameter. Pileolaria ex gr. berkeleyana are small species like $P$. connexa (no more than $2 \mathrm{~mm}$ in coil diameter when adult). They are very similar, especially in secondary replacing of the brood chamber by a «primary» operculum (Thorp, 1989) which is unusual and was not recorded for other Pileolariinae species. Nevertheless $P$. ex gr. berkeleyana have brood chamber calcification with the length twice the diameter, and with collar chaetae from the concave side of body usually much shorter than those from the convex side.

The sickle chaetae of $P$. connexa are also unusual. In most Pileolaria species the sickle chaetae have smooth and serrated blade-like regions of almost equal length, but in several species the distal serrated region is about twice as long as the proximal smoother region. The only relevant published figure (Knight-Jones, 1972, fig. 1h) of sickle with distal proximal length ratios of 4: 1 , as in $P$. connexa, is of $P$. daijonesi Knight-Jones, 1972. It must be admitted that lengths of distal regions of sickle chaetae are not reliable diagnostic characters, because those regions are rather transparent and difficult to draw. Line drawings make them look well-defined, but making those drawing often involves difficult decisions by the reviewer.

Juvenile $P$. connexa and specimens of adult size but lacking brood chambers, have primary opercula differing from the same stages of other Pileolaria species, in having a more eccentric, curved and pointed talon.

ETYMOLOGY. The species name refers to the tendency for the primary operculum to remain attached to the mature brood chamber.

ECOLOGY. Worms were collected from serpulid tubes (probably Serpula narconensis Baird, 1865), at depths of 21-172 m, intermixed with Paralaeospira sicula Knight-Jones, KnightJones 1994 and P. tegwyni. Brooding specimens (with 8-12 embryos) were observed throughout the sampling period, from the end of February to the middle of April.

DISTRIBUTION. Kerguelen Island (Indian Ocean), questionably Palmer Archipelago, Antarctic Peninsula (Southern Ocean). 


\section{Pileolaria invultuosa sp.n.} Fig. $2 \mathrm{~A}-\mathrm{Q}$.

MATERIAL EXAMINED. Holotype. MNHNP, Reg. No. UD 342A and B: A) mounted on a PVL slide without operculum; B) a mature brood chamber preserved in alcohol. R/V «Marion Dufresne» MD 24, 10/DC 15 (20.08.80), south of Bouvet Island $\left(54^{\circ} 28.2^{\prime} \mathrm{S}, 03^{\circ} 21.1^{\prime} \mathrm{E}\right)$, depth 195-203 m, on bryozoan Austroflustra australis Lopez Gappa, 1982. Paratypes. 1) MNHNP, Reg. No. UD 343 A- D - 59 specimens; KIE Reg. No. 1/2514 - 60 specimens; NHML, Reg. No. 1994.2123-2133 - 50 specimens; NMW, Reg. No. NMW.2.1993.084 — 61 specimens. Totally 221 specimens in alcohol, 9 mounted on slides (opercula detached). Label same as holotype. 2) MNHNP, Reg. No. UD $3442-1$ specimen in alcohol, XII French Antarctic Expedition to Adelie Land, south of Rostand Island, Pointe de Geologie Archipelago, St. D 55 (07.01.63) depth 8-15 m, on bivalve (Pectinidae) Adamussium colbecki (Smith, 1902). 3) MNHNP, Reg. No. UD $345-3$ specimens in alcohol, XII French Antarctic Expedition to Adelie Land, between Nunatak and Rostand Islands, Pointe de Geologie Archipelago, St. D 51/B (31.12.62), depth 10-50 m, on stones encrusted by calcareous algae, coll. P. Arnaud. 4) MNHNP, Reg. No. UD 346 - 3 specimens in ethanol, XII French Antarctic Expedition to Adelie Land, east of Carrel Island, Pointe de Geologie Archipelago, St. D 50 (31.12.62), depth 5-15 m, coll. P. Arnaud.

Other material not included in type series. MNHNP about 300 specimens, label same as holotype.

Additional doubtful material from private collection of P. \& E.W. Knight-Jones. 1) 1 specimen in alcohol. III Polish Antarctic Expedition, Alasheyev Bight, Enderby Land (15.03.74), depth 5-8 m, rocky bottom, coll. K. Jadzewski. 2) 7 specimens in alcohol ser. 410, (09.11.70) depth $3 \mathrm{~m}$, and 9 specimens in alcohol, ser. 403, Factory Cove (11.07.69), both British Antarctic Survey, Signy Island, South Orkneys.

DESCRIPTION. Tube (Fig. 2A) white, planospiral or with upward facing mouth, with irregular transverse growth lines, smooth or with 1-2 indistinct longitudinal ridges, up to 2.0 $\mathrm{mm}$ in whorl diameter when adult.

Primary operculum with slightly concave or flat calcified distal plate with almost peripheral talon, thin, often curved in lateral view, blunt or rounded terminally (Fig. 2B-D). Distal plate of primary operculum not observed to be fused to brood chamber. Calcified part of brood chamber with shallow sides, about half as long as transverse diameter either domed (Fig. 2 E-F), somewhat flattened (Fig. 2 I-J) or bilobed distally (Fig. 2G-H).

Collar and thoracic membrane with free dorsal margins. First fascicles each with 5-7 collar chaetae (Fig. $2 \mathrm{~K}$ ), each bent, fin-and- blade, with coarsely serrated and distinctly crossstriated blade, and well defined gap between the fin and the blade; 1 or 2 capillary chaetae (Fig. $2 \mathrm{~L})$ may also be present in first fascicle. Chaetae of $2^{\text {nd }}$ and $3^{\text {rd }}$ thoracic chaetigers simple (Fig. $2 \mathrm{M}$ ) with serrated blades. Sickle chaetae (Fig. $2 \mathrm{~N}$ ) also present in $3^{\text {rd }}$ fascicle, each with coarsely serrated distal and smooth basal parts of blades of similar length. Two thoracic tori on each side of body. Thoracic uncini (Fig. 2 O) short (only twice as long as abdominal uncini), with blunt anterior pegs and 1 or 2 longitudinal rows of teeth. About 10-17 abdominal chaetigers. Abdominal chaetae (Fig. 2 P) 1-2 per fascicle, flat geniculate (each with slightly projecting "knee") and distinctly serrated, tapering blade, blade lengths same as blades of collar chaetae or somewhat shorter. Hooked capillary chaetae not observed in specimens examined under a compound microscope. Abdominal uncini (Fig. 2Q) with blunt anterior peg and many longitudinal rows of teeth, distribution fairly symmetrical on both sides of body. Largest tori in middle-posterior part of abdomen. Preserved specimens uncoloured.

REMARKS. Some examined specimens with partly decalcified brood chambers and or easily macerating bodies from Enderby Land and Signy Island probably also belong to this species. Brood chamber of $P$. invultuosa differs from those of all similar species except $P$. connexa in having quite shallow sides of the distal calcification. P. moerchi, P. ex gr. berkeleyana, $P$. daijonesi and $P$. tegwyni have the brood chamber configurations distally similar to those of both $P$. connexa and $P$. invultuosa, but all species mentioned above have the dorsal calcification extending for the most or all of the length of the chamber (i.e., for about twice its diameter).

$P$. connexa differs from $P$. invultuosa in having its primary operculum commonly retained on the distal brood chamber, calcified cap on brood chamber more asymmetrical than that of $P$. invultuosa; and sickle chaetae with distal serrated part of the blade much longer than smooth basal part.

Juveniles of $P$. invultuosa are easily distinguished from those of other Pileolaria species 

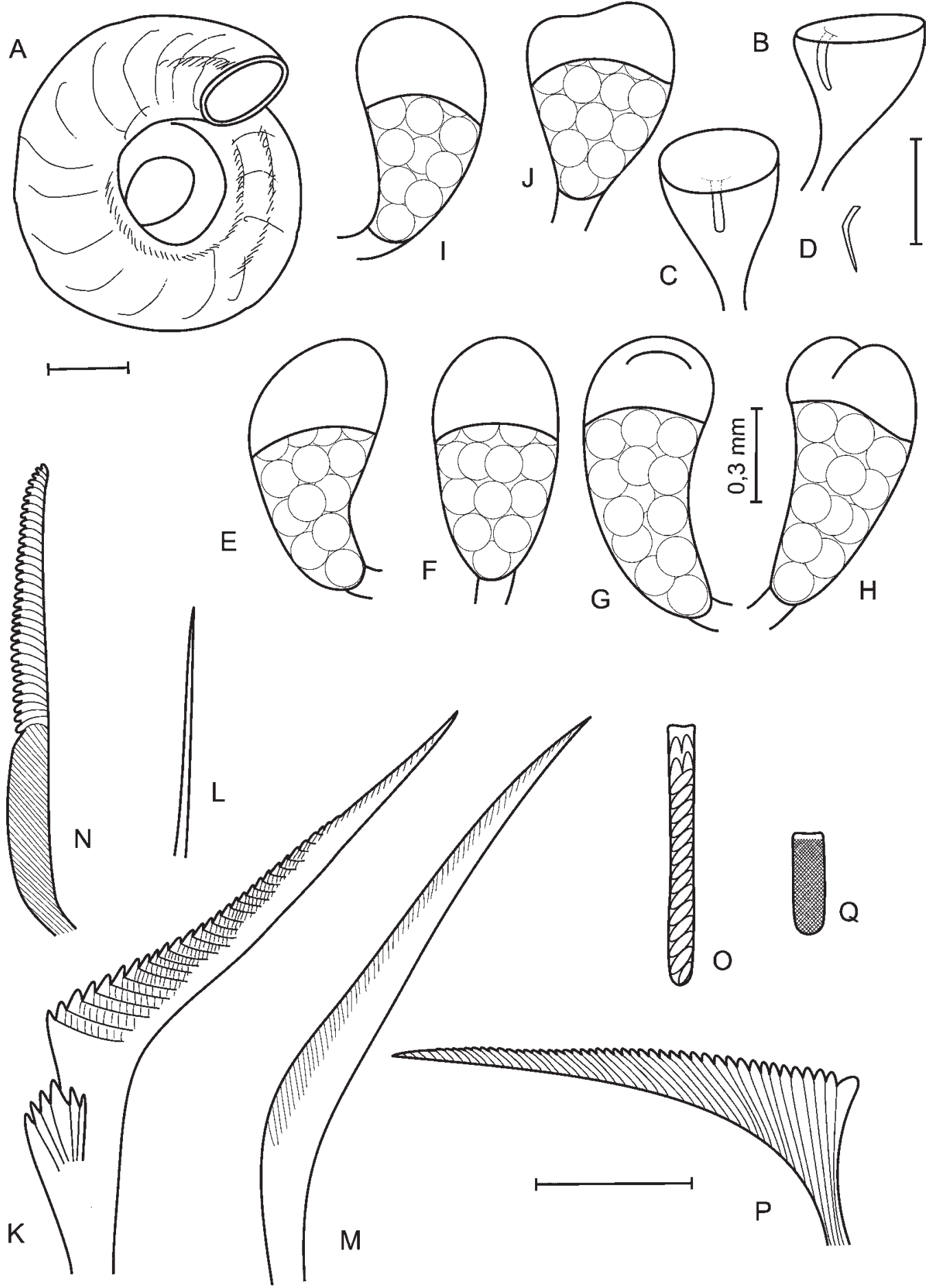
in having a very eccentric, long, thin talon of primary operculum.

ETYMOLOGY. Species name refers to a lack of any expressive feature in the shape of the calcified part of the brood chamber.

ECOLOGY. Worms were collected from bryozoans, bivalves and stones at depths of 5 $203 \mathrm{~m}$. Numerous brooding specimens were observed in a sample collected in August from Bouvet Island.

DISTRIBUTION. Bouvet (S. Atlantic) and Archipelago de Pointe Geologie, Terre Adelie (Southern Ocean). Questionably Signy Island (South Orkney Islands, S. Atlantic) and Enderby Land (Southern Ocean).

\section{Discussion}

As outlined in the Introduction, most records of $P$. berkeleyana and $P$. rosepigmentata could refer to a single variable species, $P$. berkeleya$n a$, which appears to have a wide geographic distribution and to include Spirorbis tuberculatus Bailey, Harris, 1968 from the Galapagos Islands and Easter Island (Bailey, Harris 1968; Kohn, Lloyd, 1973). These are juveniles with broad-taloned primary operculum, which is typical for P. berkeleyana (see Knight-Jones et al., 1979; Knight-Jones P, Knight-Jones E.W., 1984; Thorp et al., 1986).

During the initial stages of this study the Antarctic and Subantarctic material was tentatively identified as $P$. ex gr. berkeleyana, but detailed examinations of the primary opercula in additional material showed that two distinct Pileolaria species were present in Southern Hemisphere. Their primary opercula lack thick conical talons typical for specimens of the $P$. ex gr. berkeleyana. Juvenile characters are not often considered useful in diagnostics of invertebrates, however juvenile and primary opercula in the genus Pileolaria are equivalent to the adult opercula of tube-incubating spirorbid genera, as well as of opercula-incubating Bushiella which are usually reliable characters for species identifications.

Further studies of $P$. berkeleyana from the regions separated by great distances may lead to a re-evaluation of the berkeleyana/rosepigmentata-complex status, and may result in discovery of several sibling or pseudo-sibling species. Meanwhile the two new species described here are regarded as distinct.

\section{Acknowledgments}

I am very grateful to Helmut Zibrowius who provided these spirorbids to me and to the scientists and the crews of the research vessels that collected the material during several research cruises. Special thanks are due to Wyn Knight-Jones and the late Phyllis Knight-Jones to for their hospitality, generous help on numerous occasions and fruitful scientific discussions. The present study was supported by International Association for the promotion of co-opera-

Fig. 2. Pileolaria invultuosa sp.n.

A - tube; B, C - primary operculum, lateral and frontal views; D - curved talon of primary operculum, lateral view; E, F - mature brood chamber with hemispherical calcification distally, lateral and frontal views; G, H - brood chamber bilobed distally, lateral and dorso-lateral views; I, J — brood chamber with intermediate shape distally, lateral and frontal views; $\mathrm{K}$ - collar chaeta with fin and blade; $\mathrm{L}$ - companion capillary chaeta from $1^{\text {st }}$ chaetiger; $\mathrm{M}$ - simple chaeta from $2^{\text {nd }}$ and $3^{\text {rd }}$ chaetigers; $\mathrm{N}$ - sickle chaeta from $3^{\text {rd }}$ chaetiger; $\mathrm{O}$ - thoracic uncinus; $\mathrm{P}$ - flat geniculate abdominal chaeta with serrated blade; $\mathrm{S}-$ abdominal uncinus. Scale bars: A $-0.5 \mathrm{~mm}, \mathrm{~B}-\mathrm{J}-0.3 \mathrm{~mm}, \mathrm{~K}-\mathrm{Q}-0.02 \mathrm{~mm}$.

Fig. 2. Pileolaria invultuosa sp.n.

A - трубка; В, С - первичный оперкулюм, вид сбоку и спереди; D - изогнутый коготь первичного оперкулюма, вид сбоку; Е, F - зрелая выводковая камера, закруглённая в верхней части, вид сбоку и спереди; G, H - выводковая камера, раздвоенная в верхней части, вид сбоку и дорзо-латерально; I, J -выводковая камера с промежуточной формой верхней части, вид сбоку и спереди; $\mathrm{K}$ - воротничковая щетинка с крыловидным придатком; L - капиллярная волосовидная щетинка первого щетинкового сегмента, сопровождающая воротничковые щетинки; $\mathrm{M}$ - простая щетинка 2-го и 3-го щетинковых сегментов; $\mathrm{N}$ - серповидная щетинка 3-го щетинкового сегмента; O - торакальная анцини; P - плоская геникулирующая абдоминальная щетинка с зазубренным лезвием; S - абдоминальная анцини. Масштабы: А - 0,5 мм, B-J - 0,3 мм, K-Q - 0,02 мм. 
tion with scientists from the New Independent States of the former Soviet Union (INTAS \# 970916).

\section{References}

Bailey J.H. 1969. Spirorbinae (Polychaeta, Serpulidae) from Chios (Aegean Sea) // Zoological Journal of the Linnean Society. Vol.48. P.365-385.

Bailey J.H., Harris M.P. 1968. Spirorbinae (Polychaeta: Serpulidae) of the Galapagos Islands // Journal of Zoology, London. Vol.155. P.161-184.

Bush J.K. 1905. Tubicolous annelids of the tribes Sabellidae and Serpulidae from the Pacific Ocean // Harriman Alaskan Expedition. Vol.12. P.169-355.

Fauvel P. 1927. Polychetes Sedentaires // Faune de France. Vol. 16. P. 1-494

Harris T. 1968. Spirorbis species (Polychaeta: Serpulidae) from the Bay of Naples with the description of a new species // Pubblicazione della Stazione zoologica di Napoli. Vol.36. P.188-207.

Harris T. 1969. Spirorbis species (Polychaeta: Serpulidae) from the South Atlantic // Discovery Reports. Vol.35. P.135-178.

Hove H.A., ten. 1984. Towards a phylogeny in serpulids (Annelida; Polychaeta) // P.A. Hutchings (ed.). Proceedings of the $1^{\text {st }}$ International Polychaete Conference. Sydney: Linnean Society of New South Wales. P.181-196.

Knight-Jones E.W., Knight-Jones P. 1980. Pacific spirorbids in the East Atlantic // Journal of the Marine Biological Association of the United Kingdom. Vol.60. No.2. P.461-464.

Knight-Jones P. 1972. New species and a new subgenus of Spirorbinae (Serpulidae: Polychaeta) from Kenya // Journal of Zoology, London, 166. P.1-18.

Knight-Jones P. 1973. Spirorbinae (Serpulidae: Polychaeta) from south-eastern Australia. A new genus, four new subgenera and seven new species // Bulletin of the British Museum Natural History (Zoology). Vol.24 No.4. P.231-259.

Knight-Jones P. 1978. New Spirorbidae (Polychaeta: Sedentaria) from the East Pacific, Atlantic, Indian and Southern Oceans // Zoological Journal of the Linnean Society. Vol.64. No.3. P.201-240.

Knight-Jones P. 1984. A new species of Protoleodora (Spirorbidae: Polychaeta) from Eastern U.S.S.R. with a brief revision of related genera // Zoological Journal of the Linnean Society. Vol.88. P.109-120.

Knight-Jones P., Knight-Jones E.W. 1977. Taxonomy and ecology of British Spirorbidae (Polychaeta) // Journal of the Marine Biological Association of the United Kingdom. Vol.57. No.2. P.453-499.

Knight-Jones P., Knight-Jones E.W. 1984. Systematic, ecology and distribution of southern hemisphere spirorbids (Polychaeta: Spirorbidae) // P.A. Hutchings (ed.). Proceedings of the 1st International Polychaete Con- ference. Sydney: Linnean Society of New South Wales. P.197-210.

Knight-Jones P., Knight-Jones E.W. 1994. Spirorbidae (Polychaeta) from Signy Island, South Orkneys, including three new species // Ophelia. Vol.40. No.2. P. 75-94.

Knight-Jones P., Knight-Jones E.W., Dales R.P. 1979. Spirorbidae (Polychaeta: Sedentaria) from Alaska to Panama // Journal of Zoology, London. Vol.189. P.419-458.

Knight-Jones P., Knight-Jones E.W., Thorp C.H., Gray P.G.W. 1975. Immigrant spirorbids (Polychaeta: Sedentaria) on the Japanese Sargassum at Portsmouth, England // Zoologica Scripta. Vol.4. No.4. P.145149 .

Knight-Jones P., Thorp C.H. 1984. The opercular brood chambers of Spirorbidae // Zoological Journal of the Linnean Society. Vol.80. P.121-133.

Kohn A.J., Lloyd V.C. 1973. Marine polychaete annelids of Easter Island // Internationale Revue der gesamten Hydrobiologie. Vol.58. No.5. P.691-712.

Kupriyanova E.K. 2003. Live history evolution in serpulimorph polychaetes: a phylogenetic analysis // Hydrobiologia. Vol.496. P.105-114.

Kupriyanova E.K., Macdonalds T.A., Rouse G.W. 2006 Phylogenetic relationships within Serpulidae (Sabellida, Annelida) inferred from molecular and morphological data // Zoologica Scripta. Vol.35. No.5. P.421-439.

Levinsen G.M.R. 1883. Systematisk-geografisk Oversigt over de nordiske Annulata, Gephyrea, Chaetognathi, og Balanoglossi//Videnskabelige Meddelelser naturhistorisk Forening i Kjobenhavn, 1882. P.92-348.

Pillai T.G. 1970. Studies on a collection of spirorbids from Ceylon together with a critical review and revision of spirorbid systematics, and an account of their phylogeny and zoogeography // Ceylon Journal of Science (Biological Science). Vol.8. No.1-2. P.100-172.

Pixell H.L.M. 1912. Polychaeta from the Pacific Coast of North America. 1, Serpulidae, with a revised table of classification of the genus Spirorbis // Proceedings of the Zoological Society of London. Vol.65. P.784805

Potswald H.E. 1977. Further observations on the structure and function of the operculum in Spirorbis moerchi (Serpulidae: Spirorbinae) // Biological Bulletin of the Marine Biological Laboratory, Wood's Hole, Massachusetts. Vol.152. P.209-220.

Rioja E. 1923. Estudio sistematico de las especies Ibericas del suborden Sabelliformia // Trabajos del Museo Nacional de Ciencias Naturales Serie Zoologica. Vol.48. P.1-144.

Rioja E. 1942. Estudios anelidologicos V. Observaciones acera de algunos especies del genero Spirorbis Daudin de las costas Mexicanas del Pacifico // Anales del Instituto de biologia Universidad de Mexico. T.13. P.137-153.

Rzhavsky A.V. 1989. [Spirorbidae (Polychaeta) off the East Kamchatka shelf zone] // O.G.Kusakin (ed.). Gidrobiologicheskie issledovanija v Avachinskoj gube. 
Vladivostok: DVO RAN Press. P.50-58 [in Russian, with English summary].

Rzhavsky A.V. 1991. [Composition of the genus Bushiella (Polychaeta: Spirorbidae) and distribution of its representatives in the seas of the USSR, with description of a new species] // Zoologicheskij Zhurnal. Vol.70. No.3. P.5-11 [in Russian, with English summary].

Rzhavsky A.V. 1992. [A review of Protoleodora and Pileolaria (Polychaeta, Spirorbidae) from the seas of the USSR with the description of a new species Protoleodora gracilis] // Zoologicheskij Zhurnal. Vol.71. No.8. P.5-14 [in Russian, with English summary].

Smith R.S. 1991. Relationships within the order Sabellida (Polychaeta) // Ophelia. Suppl.5. P.249-260.

Thorp C.H. 1989. Factors affecting the formation and maintenance of the opercular brood chamber in Pileolaria (P.) berkeleyana (Polychaeta: Spirorbidae) // J.S. Ryland, P.A.Tyler (eds.). Reproduction, Genetics and Distribution of Marine Organisms. Proceedings of the $23^{\text {rd }}$ European Marine Biological Symposium. Olsen and Olsen, Fredensborg. P.211-215.
Thorp C.H., Knight-Jones P., Knight-Jones E.W. 1986. New records of tubeworms established in British harbours // Journal of the marine biological Association of the United Kingdom. Vol.66. No.4. P.881-888.

Uchida H. 1971. Spirorbinae (Polychaeta: Serpulidae) from Hokkaido II // Journal of the Faculty of Science Hokkaido University, Series 6, Zoology. Vol.18. No.1. P.193-226.

Vine P.J. 1977. The marine fauna of New Zealand: Spirorbinae (Polychaeta: Serpulidae) // Memoirs of the New Zealand Oceanographic Institute. Vol.68. P.1-66.

Zibrowius H. 1968. Étude morphologique, systématique et écologique des Serpulidae (Annelida, Polychaeta) de la région de Marseille // Recueil des Travaux de la Station marine d'Endoume, Faculté des sciences de Marseille. Vol.43. P.81-252.

Zibrowius H., Bianchi C.N. 1981. Spirorbis marioni et Pileolaria berkeleyana, Spirorbidae exotiques dans les ports de la Mediterrane nord-ocidentale // Rapport de la Commission de l'Exploration de la mer Méditerranée, Monaco. Vol.27. No.2. P.163-164.

Responsible editors: T.A. Britaev, E.N. Temereva 